\title{
水素化物生成-高出力窒素マイクロ波誘導プラズマ発光分光分析による 鉄鋼中のヒ素，ビスマス，アンチモン及びセレンの同時定量
}

\author{
松本 明弘 ${ }^{\circledR 1}$, 大枝 淳能 ${ }^{2}$, 中原 武利 ${ }^{2}$
}

\begin{abstract}
Simultaneous determination of arsenic, bismuth, antimony and selenium in steels by high power nitrogen microwave induced plasma atomic emission spectrometry coupled with hydride generation technique
\end{abstract}

Akihiro Matsumoto $^{1}$, Atsuyoshi OhedA $^{2}$ and Taketoshi NakAharA ${ }^{2}$

${ }^{1}$ Wakayama Industrial Technology Center, 60 Ogura, Wakayama-shi, Wakayama 649 - 6261

${ }^{2}$ Graduate School of Engineering, Osaka Prefecture University, Sakai-shi, Osaka 599 - 8531

(Received 10 February 2003, Accepted 15 May 2003)

\begin{abstract}
An annular-shaped high power nitrogen microwave induced plasma atomic emission spectrometry with the hydride generation method is described for the simultaneous determination of arsenic, bismuth, antimony and selenium in steels. Under the optimized experimental conditions, the best attainable detection limits at As I 228.812, Bi I 223.061, Sb I 231.147 and Se I $196.026 \mathrm{~nm}$ lines were $7.80,131,14.50 \mathrm{and} 28.99 \mathrm{ng} / \mathrm{ml}$ for arsenic, bismuth, antimony and selenium, respectively. The linear dynamic ranges for $\mathrm{As}, \mathrm{Bi}, \mathrm{Sb}$ and Se were 10 to 30000, 300 to 30000,30 to 30000 and 100 to $30000 \mathrm{ng} / \mathrm{ml}$ in concentrations, respectively. The presence of several diverse elements was found to cause more or less a depressing interference with the proposed technique. Of the several pre-reductants examined, hydrochloric acid for antimony and selenium, and potassium iodide for arsenic were found to be the most preferable to reduce $\mathrm{Sb}(\mathrm{V})$ and $\mathrm{Se}(\mathrm{VI})$ to $\mathrm{Sb}(\mathrm{III})$ and $\mathrm{Se}(\mathrm{IV})$, and $\mathrm{As}(\mathrm{V})$ to $\mathrm{As}(\mathrm{III})$, prior to hydride generation, respectively. When arsenic, bismuth, antimony and selenium in steels were determined simultaneously, a large amount of $\mathrm{Fe}(\mathrm{III})$ in the solution caused a severe depressing interference, while the presence of $\mathrm{Fe}(\mathrm{II})$ showed little or no significant interference. Of the several interferencereleasing agents examined, thiourea was found to be the most preferable to reduce $\mathrm{Fe}$ (III) to $\mathrm{Fe}(\mathrm{II})$. The concentrations of total arsenic, bismuth, antimony and selenium in steels were determined simultaneously by use of the standard additions method. The results obtained by this method were in good agreement with their certified values.
\end{abstract}

Keywords : high power nitrogen microwave induced plasma; atomic emission spectrometry; hydride generation method; simultaneous determination of arsenic bismuth antimony and selenium; steels.

\section{1 緒 言}

近年，新しいタイプの高出力（1 kW）の Okamoto 型キ

\footnotetext{
${ }^{1}$ 和歌山県工業技術センター：649-6261 和歌山県和歌山市小倉 60

2 大阪府立大学大学院工学研究科: $599-8531$ 大阪府堺市学園町 $1-1$
}

ヤビティー ${ }^{112)}$ が開発された。当初，質量分析のために開 発された，このキャビティーを用いて得られるプラズマの 大きな特徴には, 誘導結合プラズマ (ICP) と同様にドー ナツ型のプラズマを形成することができるために，従来の 低出力 (200 W 以下) マイクロ波誘導プラズマ（MIP）で は困難であった溶液試料エアロゾルの直接かつ連続導入が 可能になったこと, アルゴン ICP と比較すると, 窒素を 
プラズマガスに用いることによってアルゴンに起因する干 渉が起こらなくなることなどが挙げられる。また，窒素を キャリヤーガスとプラズマガスとして用いることにより， ランニングコストを低く抑制することができる，最近，こ の高出力 (1 kW) 窒素 MIP (以下, 高出力 $\mathrm{N}_{2}$-MIP と略記) の励起温度や電子密度の基礎的な研究が行われている ${ }^{344)}$. 一方, 高出力 $\mathrm{N}_{2}-\mathrm{MIP}$ を発光分光分析 (AES) の励起光源 として用いられた例は少なく ${ }^{3) \sim 9)}$, 更にこの高出力 $\mathrm{N}_{2-}$ MIP-AES が実試料分析に応用された研究例はあまり見ら れなく ${ }^{10) \sim 13)}$, 多元素同時定量については, 著者らの報告 に限られる ${ }^{1415)}$. 今回, 分析対象元素としてヒ素, ビスマ ス，アンチモン及びセレンを選び, MIP 中に水素化物生 成反応上って同時に発生した水素化ヒ素（アルシン）, 水 素化ビスマス (ビスムチン), 水素化アンチモン（スチビ ン）及びセレン化水素を連続的に導入して高出力 $\mathrm{N}_{2}$-MIPAES によるヒ素，ビスマス，アンチモン及びセレンの同 時定量を行った。また，水素化物生成法と通常の溶液噴霧 法とを比較した。更に本研究で開発した水素化物生成一高 出力 $\mathrm{N}_{2}$-MIP-AES $の 4$ 元素同時定量法を鉄鋼分析に応用し た。

\section{2 実験}

\section{$2 \cdot 1$ 試 薬}

七素 (III) の標準溶液は，三酸化二七素（和光純薬製特 級 98\%）を $1 \mathrm{M}$ 水酸化ナトリウム溶液 $25 \mathrm{ml}$ に溶解後，4 $\mathrm{M}$ 塩酸 $10 \mathrm{ml}$ を加え, 純水で希釈して調製した. 七素 $(\mathrm{V})$ の標準溶液は，五酸化二七素（Merck 製特級 99\%）を純 水で希䣋して調製した。

ビスマス標準溶液は，ビスマス金属（純度 99.999\%） を $6.5 \mathrm{M}$ 硝酸に溶解後, $1.2 \mathrm{M}$ 硝酸で希釈して調製した。

アンチモン (III) の標準溶液は, 酒石酸アンチモニルカ リウム（和光純薬製特級 $99.8 \%$ ）を純水に溶解し, 希釈 して調製した。アアンチモン $(\mathrm{V})$ の標準溶液は, Fodor ら ${ }^{12)}$ の方法を用いて，五塩化アンチモン（和光純薬製特級 $90 \%)$ を $5 \%$ 塩酸と $0.5 \%$ 酒石酸を含む溶液に溶かして調 製した。この標準溶液中の濃度を, 先述のアンチモン $(\mathrm{III})$ 標準溶液を用いて溶液噴霧法による $\mathrm{N}_{2}$-MIP-AES で正確に 決定した.

セレン（IV）の標準溶液は，二酸化セレン（和光純薬製 特級 97\%）を純水で溶かして調製した。セレン（VI）の標 準溶液は，セレン酸ナトリウム（和光純薬製 1 級 97\%) を純水で溶かして調製した。水素化物生成法の測定の際に は，3.3で後述する予備還元の場合を除き，七素(III)，ア ンチモン（III）及びセレン（IV）の標準溶液を純水で希釈 して用いた。

水素化物生成反応の前に, 七素 $(\mathrm{V})$ から七素(III)， ア ンチモン (V) からアンチモン (III) 及びセレン (VI) から
セレン (IV) へ予備還元するのに塩酸, チオ尿素とヨウ化 カリウムを用いた。また，鉄鋼の主成分である鉄による干 渉を抑制するのにチ才尿素と L-アスコルビン酸を用いて検 討した。

水素化物生成反応の還元剂として用いたテトラヒドロホ ウ酸ナトリウム $\left(\mathrm{NaBH}_{4}\right)$ 溶液は, 試薬を純水に溶かし， 水酸化ナトリウムで弱アルカリ性にして調製した。この溶 液は測定の日ごとに調製して用いた。

その他の試薬は，有害金属測定用又は原子吸光分析用試 薬を用いた。なお，試料の分解に用いた酸類は，試薬特級 品を用いた。

標準試料の調製，試料分解や希釈に用いた純水は，すべ て Milli-Qシステム（日本ミリポア製）で製造した。

\section{$2 \cdot 2$ 装置及び実験操作}

本研究で使用した装置全体の概略を Fig. 1 に示し，主 要な装置の型式及びメーカーを Table 1 に示す．自家製の 水素化物発生装置をこれらと組み合わせて用いた。また， プラズマ中での測光位置の調整のために，マイクロ波電源 (マグネトロンを含む) (Fig. 1 中の B), MIP キャビティー (h)，ネブライザーチャンバー（V) などは一体化されて， 特注した可動台上に固定されている。この可動台を上下． 前後に微動することによって，プラズマ中の測光位置を調 整・最適化した。

水素化物生成反応の場合には，七素，ビスマス，アンチ モン及びセレンを含む混合標準あるいは試料溶液と還元剤 $\left(\mathrm{NaBH}_{4}\right)$ 溶液をペリスタポンプ（Fig. 1 中のd）で連続 的に送液・混合し, 気一液分離器 (e) 内に窒素ガスを通 気することによって同時に発生した各元素の水素化物を溶 液マトリックスから分離し，ネブライザーチャンバー（V) のドレインロから MIP（i）中に導入した. ヒ素, ビスマ ス，アンチモン及びセレンに対する水素化物生成一高出力 N2-MIP-AES の最適化された条件を Table 2 に示し, 幾つ かの測定条件の最適化については後述する.

\section{$2 \cdot 3$ 試料の溶解}

鉄鋼試料には，アメリカの国家標準（NIST）の鉄鋼認 証物質 $361 ， 363$ を用いた。試料 $1.0 \mathrm{~g}$ をビーカーに精ひ ょうし， $10 \mathrm{ml}$ の王水を加え，ホットプレート上で加熱し て完全に溶解した，放冷後, 塩酸で酸性度を調整して, $80^{\circ} \mathrm{C}$ で 20 分間加温し, 放冷後, $100 \mathrm{ml}$ のメスフラスコ に移し，純水で定容にした．更にこの溶液から 4 個の 100 $\mathrm{ml}$ のメスフラスコにそれぞれ $20 \mathrm{ml}$ 分取し, 既知の七素, ビスマス，アンチモン及びセレンの標準溶液をそれぞれに 添加し, 塩酸で酸性度を調整して純水を加えて $100 \mathrm{ml}$ に 定容にした。これらを七素，ビスマス，アンチモン及びセ レンの同時定量のための試料溶液とした. 


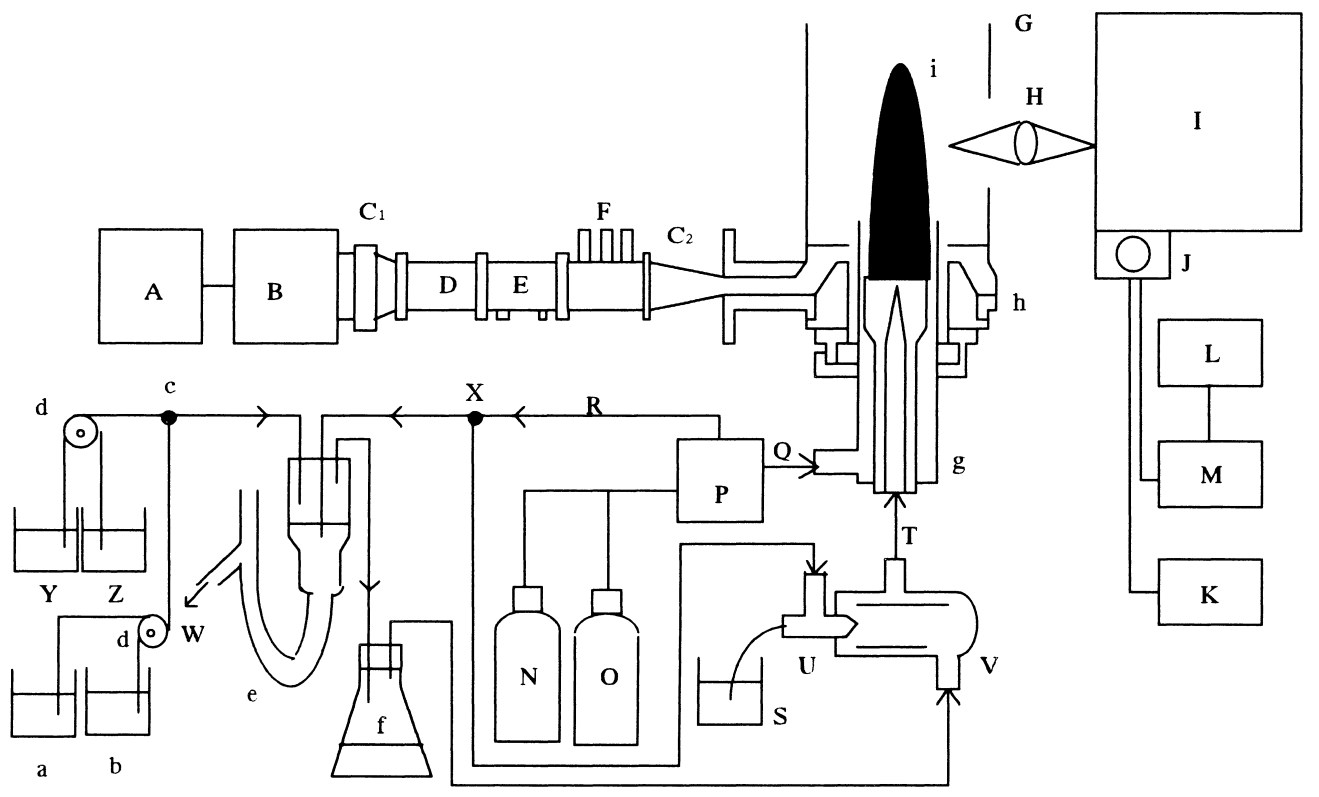

Fig. 1 Schematic diagram of high power $\mathrm{N}_{2}$-MIP-AES system

A: microwave power supply; $\mathrm{B}$ : microwave generator; $\mathrm{C}_{1}, \mathrm{C}_{2}$ : tapered wave guide; $\mathrm{D}$ : uniline ; E : direction coupler; F : three-stub tuner; G: copper pipe; $\mathrm{H}$ : lens; I: monochromator; J : photomultiplier; K: high-voltage power supply; L: printer; M: computer; $\mathrm{N}$ : nitrogen tank; O : argon tank; P: gas controller; Q: plasma gas; R: carrier gas; $\mathrm{S}$ : sample solution for nebulization; $\mathrm{T}$ : carrier gas for sample aerosol or hydride; $\mathrm{U}$ : nebulizer; $\mathrm{V}$ : nebulizer chamber ; $\mathrm{W}$ : waste; $\mathrm{X}$ : three-way stopcock; Y: sample solution for hydride generation; $\mathrm{Z}: \mathrm{NaBH}_{4}$ solution; a: pre-reduction solution for elements; b: interferece-releasing solution for iron; $\mathrm{c}$ : mixing joint; $d$ : peristaltic pump; e: gas-liquid separator; $f$ : drying flask; $g$ : discharge tube (plasma torch); h: cavity; i: plasma

Table 1 Experimental instrumentation for high power $\mathrm{N}_{2}$-MIP-AES

\begin{tabular}{lll}
\hline Component & Model & Manufacturer \\
\hline Microwave generator & MKN-103-3S & Nippon Kousyuha \\
Microwave cavity & Okamoto cavity & Hitachi \\
MIP torch & 300-8352 & Hitachi \\
Sequential spectrometer & Part of ICAP-575 & Nippon Jarrell-Ash \\
Photomultipliers & R427 and R550 & Hamamatsu Photonics \\
Personal computer & PC-9821 & NEC \\
Peristaltic pump & MP-3 & Tokyo Rikakikai \\
\hline
\end{tabular}

3 結果と考察

\section{$3 \cdot 1$ 測定条件の最適化}

$3 \cdot 1 \cdot 1$ 測定波長 最適測定条件は, ヒ素, ビスマス, アンチモン及びセレンの正味の発光強度 $\left(I_{\mathrm{n}}\right)$ とバックグ ラウンド強度 $\left(I_{\mathrm{b}}\right)$ の比, $I_{\mathrm{n}} / I_{\mathrm{b}}$ 值が最大, 又は 4 元素の $I_{\mathrm{n}} / I_{\mathrm{b}}$ が最大に近い值になる条件とした。但し，発光強度 $\left(I_{\mathrm{n}}\right)$ は, 測定されるヒ素, ビスマス，アンチモン及びセ レンの発光強度から試薬ブランクを含むバックグラウンド 強度 $\left(I_{\mathrm{b}}\right)$ を差し引くことにより求めた.

ヒ素，ビスマス，アンチモン及びセレンに対して，溶液 噴霧法及び水素化物生成法を適用した場合の $\mathrm{N}_{2}-\mathrm{MIP}$ 発光
スペクトルの波長走査を行った。 その結果，190～310 $\mathrm{nm}$ の波長範囲で，ヒ素の 5 本，ビスマスの 5 本，アンチ モンの 4 本及びセレンの 5 本の主要な発光スペクトル線 が観測された。これらの発光スペクトル線について発光特 性を調べ，その結果を Table 3 に示す。この結果から，ヒ 素, ビスマス, アンチモン及びセレンの分析線として, 最 大の $I_{\mathrm{n}} / I_{\mathrm{b}}$ 值が得られた As I 228.812，Bi I 223.061，Sb I 231.147 及び Se I $196.026 \mathrm{~nm}$ 線を選び，以下の実験に用 いた.

$3 \cdot 1 \cdot 2$ 還元剤の濃度水素化物生成反応の還元剂と して用いたテトラヒドロホウ酸ナトリウム溶液の濃度はヒ 素，ビスマス，アンチモン及びセレンの水素化物生成効率 に大きな影響を与えることがよく知られている ${ }^{16) ~ 20)}$. 本 研究において， $0.5 \%$ 水酸化ナトリウムのアルカリ性下で テトラヒドロホウ酸ナトリウム溶液の濃度をすべての元素 で $0.1 \sim 0.7 \%$ の範囲で検討し，最適化を行った。 その結 果は Table 2 に示すとおりである. 最適濃度を $0.6 \%$ とし, 以下の実験に用いた。また，Table 2 には還元剂溶液の最 適な送液流量も示した.

$3 \cdot 1 \cdot 3$ 酸の濃度 還元剤の濃度とともに, 水素化物 生成に用いる塩酸の濃度も七素，ビスマス，アンチモン及 びセレンの水素化物生成効率に大きな影響を与える ${ }^{16) \sim 20)}$. 
Table 2 Optimized operating conditions for the simultaneous determination of arsenic, bismuth, antimony and selenium by high power $\mathrm{N}_{2}$-MIP-AES with solution nebulization and continuous-flow hydride generation

\begin{tabular}{|c|c|c|}
\hline & $\begin{array}{c}\text { Solution } \\
\text { nebulization }\end{array}$ & $\begin{array}{c}\text { Hydride } \\
\text { generation }\end{array}$ \\
\hline \multicolumn{3}{|l|}{ Plasma } \\
\hline \multirow[t]{4}{*}{ Wavelength/nm } & As I 228.812 & As I 228.812 \\
\hline & Bi I 223.061 & Bi I 223.061 \\
\hline & Sb I 231.147 & Sb I 231.147 \\
\hline & Se I 196.026 & Se I 196.026 \\
\hline Microwave forward power/W & 1000 & 1000 \\
\hline Plasma gas flow rate $/ 1 \mathrm{~min}^{-1}$ & 14 & 12 \\
\hline Carrier gas flow rate $/ 1 \mathrm{~min}^{-1}$ & 1.1 & 0.2 \\
\hline $\begin{array}{l}\text { Vertical observation position/mm } \\
\text { (above the top of the cavity) }\end{array}$ & 4 & 4 \\
\hline Horizontal observation position/mm & 0 (centered) & 0 (centered) \\
\hline \multicolumn{3}{|l|}{ Hydride geberation } \\
\hline $\mathrm{NaBH}_{4}$ concentration, $\%$ & & 0.6 \\
\hline $\mathrm{NaOH}$ concentration, $\%$ & & 0.4 \\
\hline Sample acidify ( $\mathrm{M}$ in $\mathrm{HCl})$ & & 2.0 \\
\hline Sample solution flow rate $/ \mathrm{ml} \mathrm{min}^{-1}$ & & 7.4 \\
\hline $\mathrm{NaBH}_{4}$ solution flow rate $/ \mathrm{ml} \mathrm{min}{ }^{-1}$ & & 11.2 \\
\hline
\end{tabular}

Table 3 Emission characteristics of major lines of arsenic, bismuth, antimony and selenium by high power $\mathrm{N}_{2}$-MIP-AES with solution nebulization and continuous-flow hydride generation

\begin{tabular}{|c|c|c|c|c|c|c|}
\hline \multirow{2}{*}{$\begin{array}{c}\text { Wavelength/ } \\
\text { nm }\end{array}$} & \multicolumn{3}{|c|}{$\begin{array}{c}\text { Solution } \\
\text { nebulization }^{\text {a) }}\end{array}$} & \multicolumn{3}{|c|}{$\begin{array}{c}\text { Hydride } \\
\text { generation }^{\mathrm{b})}\end{array}$} \\
\hline & $I_{\mathrm{n}}^{\mathrm{c})}$ & $I_{\mathrm{n}} / I_{\mathrm{b}}^{\mathrm{c}}$ & $\mathrm{BEC}^{\mathrm{d})}$ & $I_{\mathrm{n}}^{\mathrm{c})}$ & $I_{\mathrm{n}} / I_{\mathrm{b}}^{\mathrm{c}}$ & $\mathrm{BEC}^{\mathrm{d})}$ \\
\hline As I 189.042 & 0.06 & 1.36 & 36.7 & 0.01 & 0.36 & 14.01 \\
\hline As I 193.759 & 0.07 & 1.18 & 42.4 & 0.01 & 0.78 & 6.39 \\
\hline As I 197.262 & 0.06 & 1.03 & 48.4 & 0.02 & 0.80 & 6.26 \\
\hline As I 200.334 & 0.13 & 2.13 & 23.4 & 0.12 & 11.29 & 0.44 \\
\hline As I 228.812 & 1.00 & 12.47 & 4.01 & 1.00 & 72.43 & 0.07 \\
\hline Bi I 195.389 & 0.05 & 1.21 & 41.2 & 0.50 & 1.05 & 4.77 \\
\hline Bi I 206.170 & 0.23 & 0.91 & 54.8 & 0.23 & 1.07 & 4.67 \\
\hline Bi I 222.825 & 0.54 & 1.91 & 26.2 & 0.15 & 0.61 & 8.25 \\
\hline Bi I 223.061 & 1.00 & 2.75 & 18.2 & 1.00 & 2.49 & 2.01 \\
\hline Bi I 306.772 & 0.27 & 2.71 & 18.5 & 0.10 & 0.56 & 8.97 \\
\hline Sb I 206.833 & 0.45 & 6.64 & 7.53 & 0.41 & 29.42 & 0.17 \\
\hline Sb I 217.581 & 0.52 & 8.86 & 5.64 & 0.69 & 46.33 & 0.11 \\
\hline Sb I 231.147 & 0.65 & 14.74 & 3.39 & 0.81 & 62.82 & 0.02 \\
\hline Sb I 259.807 & 1.00 & 14.23 & 3.51 & 1.00 & 62.68 & 0.08 \\
\hline Se I 196.026 & 1.00 & 2.34 & 21.4 & 1.00 & 14.13 & 0.35 \\
\hline Se I 199.511 & 0.19 & 0.83 & 60.4 & 0.05 & 0.53 & 9.46 \\
\hline Se I 203.985 & 0.27 & 2.23 & 22.5 & 0.76 & 12.59 & 0.40 \\
\hline Se I 206.279 & 0.34 & 1.20 & 41.8 & 0.50 & 4.50 & 1.11 \\
\hline Se I 206.479 & 0.06 & 0.92 & 54.5 & 0.14 & 1.21 & 4.13 \\
\hline
\end{tabular}

a) With solutions containing $\mathrm{As}, \mathrm{Bi}, \mathrm{Sb}$ and $\mathrm{Se}(50 \mu \mathrm{g} / \mathrm{ml})$; b) With solutions containing As, Bi, Sb and Se $(5 \mu \mathrm{g} / \mathrm{ml})$; c) Relative to $I_{\mathrm{n}}$ of As I 228.812, Bi I 223.061, Sb I 231.147 and Se I $196.026 \mathrm{~nm}$; d) Background equivalent concentration ( $\mu \mathrm{g}$ $\mathrm{As}, \mathrm{Bi}, \mathrm{Sb}$ or $\mathrm{Se} / \mathrm{ml}$ )

塩酸の濃度を $0.1 〜 4.0 \mathrm{M}$ の範囲で検討し, 最適化を行っ た。その結果は Table 2 に示すとおりである. 最適濃度を $2 \mathrm{M}$ とし，以下の実験に用いた。

\section{$3 \cdot 2$ 測定感度}

試料導入法として，溶液噴霧法を用いて Table 2 に示す ような最適条件下で得られたヒ素とアンチモンの検量線 は，共に 1〜1000, ビスマスは 10〜 1000, セレン 3〜 $1000 \mu \mathrm{g} / \mathrm{ml}$ の範囲で直線となり，その相関係数はすべて 0.999 であった。得られた検出限界（バックグラウンド強 度を 10 回測定したときの標準偏差の 3 倍の発光強度を与 える分析の濃度で，いわゆる $3 \sigma$ 検出限界）は，ヒ素，ビ スマス，アンチモン及びセレンでそれぞれ $0.68 ， 3.79$ ， 0.91 及び $1.83 \mu \mathrm{g} / \mathrm{ml}$ であった.これらの值は同じ方法で 単元素測定したときの検出限界 \{ヒ素 $(0.45 \mu \mathrm{g} / \mathrm{ml})^{11)}$, アンチモン $(0.51 \mu \mathrm{g} / \mathrm{ml})^{12)}$, セレン $\left.(1.09 \mu \mathrm{g} / \mathrm{ml})^{11)}\right\}$, 更に 2 元素（ヒ素とアンチモン）及び 3 元素（ヒ素，ビス マスとアンチモン）を同時定量したときの検出限界（ヒ 素 $(0.65 \mu \mathrm{g} / \mathrm{ml})$ とアンチモン $(0.59 \mu \mathrm{g} / \mathrm{ml})\}^{14)}$ 及び 化素 $(0.61 \mu \mathrm{g} / \mathrm{ml})$ ，ビスマス $(3.7 \mu \mathrm{g} / \mathrm{ml})$ とアンチモ ン $(0.58 \mu \mathrm{g} / \mathrm{ml})\}^{15)}$ と比較してほぼ近い值であった。一 方，水素化物生成法を用いて Table 2 に示すような最適条 件下で得られた検量線は，ヒ素，ビスマス，アンチモン及 びセレンでそれぞれ 10～30000，300～30000，30〜 30000 及び $100 \sim 30000 \mathrm{ng} / \mathrm{ml}$ の濃度範囲で良好な直線性 を示した。その相関係数は 4 元素共 0.999 であった，得ら れた検出限界は, ヒ素, ビスマス, アンチモン及びセレン でそれぞれ 7.80，131，14.50 及び $28.99 \mathrm{ng} / \mathrm{ml}$ であった。 これらの值は，同じ方法で単元素測定したときの検出限界 \{ ヒ素 $(2.99 \mathrm{ng} / \mathrm{ml})^{11)}$, アンチモン $(1.87 \mathrm{ng} / \mathrm{ml})^{12)}$, セ レン $\left.(0.86 \mathrm{ng} / \mathrm{ml})^{11)}\right\}$, 更に 2 元素（ヒ素とアンチモン） 及び 3 元素（ヒ素，ビスマスとアンチモン）を同時定量 したときの検出限界 \{ヒ素 $(4.13 \mathrm{ng} / \mathrm{ml})$ とアンチモン 


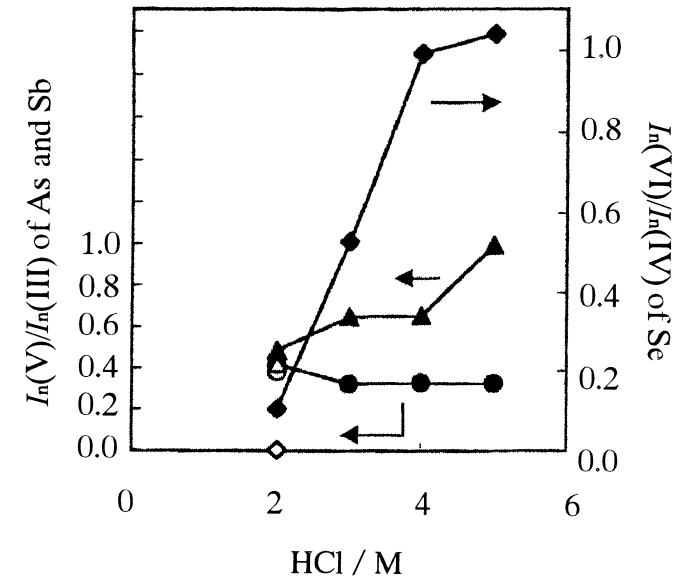

Fig. 2 Effect of $\mathrm{HCl}$ concentration on emission intensity ratios of $\mathrm{As}(\mathrm{V})$ to $\mathrm{As}(\mathrm{III}), \mathrm{Sb}(\mathrm{V})$ to $\mathrm{Sb}(\mathrm{III})$ and $\mathrm{Se}(\mathrm{VI})$ to $\mathrm{Se}(\mathrm{IV})$

$\bigcirc$ : arsenic; $\boldsymbol{\Delta}, \triangle$ : antimony; $\diamond, \diamond$ : selenium; $\boldsymbol{\sim}, \boldsymbol{\Delta}, \diamond$ : heating at $80^{\circ} \mathrm{C} ; \bigcirc, \triangle, \diamond$ : no heating

$(4.50 \mathrm{ng} / \mathrm{ml})\}^{14)}$ 及び $\{$ ヒ素 $(7.13 \mathrm{ng} / \mathrm{ml})$, ビスマス $(116.13 \mathrm{ng} / \mathrm{ml})$ とアンチモン $(14.60 \mathrm{ng} / \mathrm{ml})\}^{15)}$ と比較し てやや劣る值であった。 これは, 単元素分析と比較して, より水素化ホウ素ナトリウムを消費するために水素化物生 成効率に大きく影響したこと, 多元素分析における最適条 件が個々の元素の最適条件からずれることが原因と考えら れる. しかし, 七素の検出限界は, 単元素分析した場合と 他の元素と同時分析した場合と比較して，あまり低下して いないことが分かった。 また, 水素化物生成一高周波誘導 結合プラズマ発光分光分析法 ${ }^{16)}$ や水素化物生成 - 電気加熱 原子吸光法 ${ }^{22)}$ を用いて同時定量を行った場合, ヒ素, ビス マス，アンチモン及びセレンの検出限界は，それぞれ 0.03，0.06，0.07 及び $0.04 ， 0.82 ， 0.04 ， 0.26$ 及び 0.29 $\mathrm{ng} / \mathrm{ml}$ と報告されている。これらの報告值と比較すると, 本法による検出限界值が劣っていることが分かった.

\section{$3 \cdot 3$ 予備還元}

一般に，実試料を酸溶解した場合には，ビスマスは 3 価の酸化状態で存在するが，ヒ素及びアンチモンはヒ素 (III) とヒ素 (V) 及びアンチモン (III) とアンチモン (V), セレンはセレン (IV) とセレン (VI) のそれぞれ 2 種類の 酸化状態で存在する。 それぞれのヒ素, アンチモン及びセ レンからアルシン, スチビン及びセレン化水素の発生効率 は大きく異なる，実際に本実験で測定した結果，七素，ア ンチモン及びセレンの高い酸化数の溶液から水素化物の発 生効率は低い酸化数の溶液を用いた場合のそれぞれ約 38 , 42 及び $1 \%$ であった。したがって, 試料溶液中のヒ素, アンチモン及びセレンの全量を測定する場合には, 水素化 物生成反応の前にヒ素 $(\mathrm{V})$ からヒ素 (III), アンチモン (V)

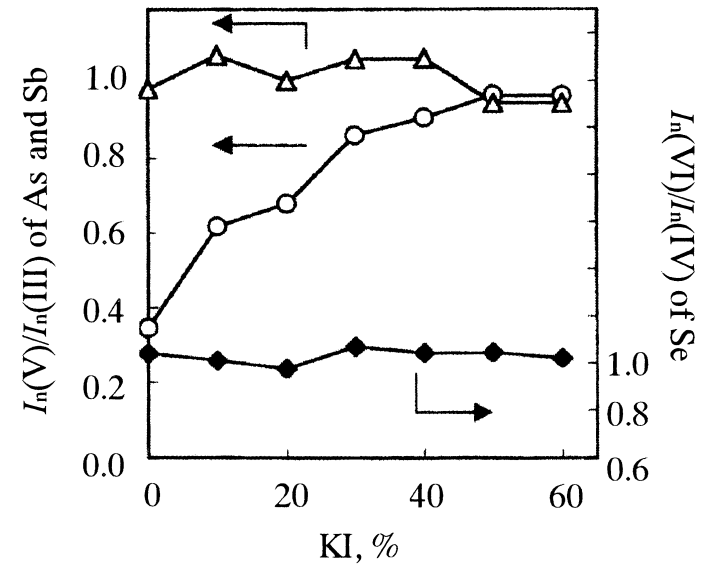

Fig. 3 Effect of KI concentration on emission intensity ratios of $\mathrm{As}(\mathrm{V})$ to $\mathrm{As}(\mathrm{III})(\bigcirc), \mathrm{Sb}(\mathrm{V})$ to $\mathrm{Sb}(\mathrm{III})(\triangle)$ and $\mathrm{Se}(\mathrm{VI})$ to $\mathrm{Se}(\mathrm{IV})$

からアンチモン (III) 及びセレン(VI) からセレン (IV) の予備還元操作を必要とした。水素化物生成法において, ヒ素とアンチモンの予備還元にチオ尿素 ${ }^{1026)}$ やヨウ化カリ

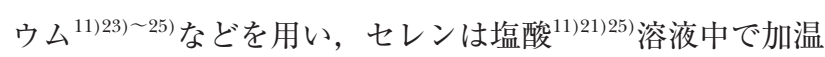
することにより予備還元した報告がある。そこで本研究で は, $1 \mu \mathrm{g} / \mathrm{ml}$ のヒ素(V) とアンチモン $(\mathrm{V}), 5 \mu \mathrm{g} / \mathrm{ml}$ のセ レン $(\mathrm{VI})$ を含む混合溶液を 2〜 $5 \mathrm{M}$ の濃度範囲の塩酸溶 液中 $80^{\circ} \mathrm{C}$ で 20 分加温することによる予備還元の検討を 行い, その結果を Fig. 2 に示す。ここで, 眓中の $I_{\mathrm{n}}(\mathrm{V}) /$ $I_{\mathrm{n}}(\mathrm{III})$ は，七素(III) とアンチモン (III) だけ含む溶液を用 いて得られる発光強度 $\left\{I_{\mathrm{n}}(\mathrm{III})\right\}$ に対する, ヒ素 $(\mathrm{V})$ とア ンチモン $(\mathrm{V})$ だけを含む溶液からの発光強度 $\left\{I_{\mathrm{n}}(\mathrm{V})\right\}$ の 比である。同様に, 図中の $I_{\mathrm{n}}(\mathrm{VI}) / I_{\mathrm{n}}(\mathrm{IV})$ は, セレン (IV) だけ含む溶液を用いて得られる発光強度 $\left\{I_{n}(\mathrm{IV})\right\}$ に対す る，セレン $(\mathrm{VI})$ だけを含む溶液からの発光強度 $\left\{I_{\mathrm{n}}(\mathrm{VI})\right\}$ の比である。この結果より，塩酸濃度を $5 \mathrm{M}$ にして加温 することでアンチモンとセレンの発光強度はほぼ完全に回 復した。しかし，七素の発光強度はほとんど回復せず，塩 酸酸性下で加温することによってヒ素 (III) に還元されな かった。したがって，七素を予備還元するために別にチ才 尿素 ${ }^{10) 26)}$ とヨウ化カリウム ${ }^{11) 23) ~ 25)}$ を用い，それぞれ $0.1 〜$ $1 \%$ と 10 ～60\% の濃度範囲で変化させて加えたときのヒ 素，アンチモン及びセレンの発光強度を測定した。その結 果, チオ尿素を添加した場合, 七素の発光強度はほとんど 回復しなかった。一方, Fig. 3 に示すように，ヨウ化カリ ウムをオンライン（Fig. 1 中の a) で添加した場合, 添加 濃度を $50 \%$ 以上にすることでヒ素の発光強度は完全に回 復した。また，アンチモンとセレンの発光強度は変化しな かった。したがって，後で述べる鉄鋼試料の分析では，試 料溶液を $5 \mathrm{M}$ の塩酸溶液中で加温し, $50 \%$ のヨウ化カリ ウムをオンラインで添加してヒ素, アンチモン及びセレン 
Table 4 Effect of diverse elements or ions on the simultaneous determination of arsenic, bismuth, antimony and selenium by high power $\mathrm{N}_{2}$-MIP-AES with hydride generation

\begin{tabular}{|c|c|c|c|c|c|}
\hline \multirow{2}{*}{ Element or ion ${ }^{a)}$} & \multirow{2}{*}{ Added as } & \multicolumn{4}{|c|}{ Relative intensity ${ }^{\text {b) }}$} \\
\hline & & Arsenic & Bismuth & Antimony & Selenium \\
\hline $\mathrm{Ag}$ & $\mathrm{AgNO}_{3}$ & 91.8 & 31.8 & 94.3 & 6.9 \\
\hline $\mathrm{Cd}$ & $\mathrm{Cd}\left(\mathrm{NO}_{3}\right)_{2} \cdot 4 \mathrm{H}_{2} \mathrm{O}$ & 58.8 & 2.3 & 93.0 & 2.5 \\
\hline Co & Metal in $\mathrm{HCl}$ & 33.9 & 84.4 & 30.4 & 36.8 \\
\hline $\mathrm{Cr}(\mathrm{VI})$ & $\mathrm{K}_{2} \mathrm{Cr}_{2} \mathrm{O}_{7}$ & 86.5 & 71.1 & 72.1 & 43.3 \\
\hline $\mathrm{Cu}$ & $\mathrm{CuSO}_{4} \cdot 5 \mathrm{H}_{2} \mathrm{O}$ & 45.6 & 31.7 & 38.5 & 3.0 \\
\hline $\mathrm{Fe}(\mathrm{III})$ & $\mathrm{FeCl}_{3} \cdot 6 \mathrm{H}_{2} \mathrm{O}$ & 27.3 & 42.8 & 33.7 & 24.3 \\
\hline $\mathrm{Ge}$ & $\mathrm{GeO}_{2}$ & $-^{c)}$ & - & - & 13.9 \\
\hline In & Metal in $\mathrm{HNO}_{3}$ & - & - & - & 20.4 \\
\hline $\mathrm{Ni}$ & $\mathrm{NiSO}_{4} \cdot 6 \mathrm{H}_{2} \mathrm{O}$ & 22.9 & 9.2 & 24.9 & 6.1 \\
\hline $\mathrm{Pb}$ & $\mathrm{Pb}\left(\mathrm{NO}_{3}\right)_{2}$ & 56.3 & 65.7 & 83.9 & 1.3 \\
\hline $\mathrm{Pd}$ & $\mathrm{PdCl}_{2}$ & 19.6 & 87.9 & 15.9 & 0.8 \\
\hline Sn & Metal in $\mathrm{HCl}$ & 80.2 & 85.9 & 31.7 & 3.9 \\
\hline $\mathrm{Te}$ & $\mathrm{Na}_{2} \mathrm{TeO}_{3}$ & 60.9 & 49.9 & 38.9 & - \\
\hline $\mathrm{Ti}$ & Metal in $\mathrm{HCl}$ & - & - & - & 2.0 \\
\hline $\mathrm{V}$ & $\mathrm{NH}_{4} \mathrm{VO}_{3}$ & 70.7 & - & 85.6 & 77.5 \\
\hline W & $\mathrm{Na}_{2} \mathrm{WO}_{4} \cdot 2 \mathrm{H}_{2} \mathrm{O}$ & 74.5 & 18.4 & 35.6 & 52.5 \\
\hline $\mathrm{Zn}$ & Metal in $\mathrm{HCl}$ & 64.4 & - & 60.0 & 74.3 \\
\hline $\mathrm{Zr}$ & $\mathrm{ZrO}\left(\mathrm{NO}_{3}\right)_{2} \cdot 2 \mathrm{H}_{2} \mathrm{O}$ & - & - & - & 63.5 \\
\hline $\mathrm{BrO}_{3}^{-}$ & $\mathrm{KBrO}_{3}$ & 29.9 & - & 17.3 & 3.2 \\
\hline $\mathrm{ClO}_{3}{ }^{-}$ & $\mathrm{NaClO}_{3}$ & 37.1 & 68.2 & 36.9 & 3.9 \\
\hline $\mathrm{IO}_{3}{ }^{-}$ & $\mathrm{KIO}_{3}$ & 25.5 & - & 33.3 & 1.7 \\
\hline $\mathrm{NO}_{2}{ }^{-}$ & $\mathrm{NaNO}_{2}$ & 30.0 & 61.6 & 27.3 & 0.8 \\
\hline
\end{tabular}

a) Diverse element or ion added at level of $1000 \mu \mathrm{g} / \mathrm{ml}$; b) Relative to 100 for the emission intensity of As ( $1 \mu \mathrm{g} / \mathrm{ml}), \mathrm{Bi}(5 \mu \mathrm{g} / \mathrm{ml}), \mathrm{Sb}$ $(1 \mu \mathrm{g} / \mathrm{ml})$ and Se $(5 \mu \mathrm{g} / \mathrm{ml})$; c) No inerference

を予備還元することにした。

\section{$3 \cdot 4$ 共存種の影響}

水素化物生成法では, 測定溶液中の七素, ビスマス, ア ンチモン及びセレンを還元反応によってガス状のアルシ ン, ビスムチン, スチビン及びセレン化水素に変換し, 溶 液マトリックスから分離してプラズマ中に導入するので, 主としてこの水素化物生成反応の際の共存元素（化学種） による化学的な干渉が起こる ${ }^{17) ~ 21)}$. 七素, ビスマス, ア ンチモン及びセレンの混合溶液に対して 1000 倍量（ビス マスとセレンの場合は 200 倍量) の化学種が存在したと きのヒ素, ビスマス，アンチモン及びセレンの発光強度を 測定し，干渉の有無を検討した。干渉を示した元素及びそ の干渉の度合いを，七素，ビスマス，アンチモン及びセレ ンの混合溶液のみの発光強度に対する相対強度で求めた結 果を Table 4 に示す. 但し, 相対強度が $100 \pm 5$ 以内の值 を示した元素 $\{\mathrm{Al}, \mathrm{B}, \mathrm{Ba}, \mathrm{Ca}, \mathrm{Ce}, \mathrm{Cr}(\mathrm{III}), \mathrm{Cs}, \mathrm{Fe}(\mathrm{II})$, $\mathrm{Ga}, \mathrm{K}, \mathrm{Li}, \mathrm{Mg}, \mathrm{Mn}, \mathrm{Mo}, \mathrm{Na}, \mathrm{P}, \mathrm{Rb}, \mathrm{Sr}, \mathrm{Br}^{-}, \mathrm{Cl}^{-}$, $\mathrm{CN}, \mathrm{CO}_{3}{ }^{2-}, \mathrm{C}_{2} \mathrm{O}_{4}{ }^{2-}, \mathrm{F}^{-}, \mathrm{HCO}_{3}{ }^{-}, \mathrm{NH}_{4}{ }^{+}, \mathrm{NO}_{3}{ }^{-}$, $\left.\mathrm{SCN}^{-}, \mathrm{SO}_{3}{ }^{2-}, \mathrm{SO}_{4}{ }^{2-}\right\}$ は, 測定誤差を考虑して干渉がな いものとした。この結果から, コバルト, 銅, 鉄 (III), ニッケルなどの共存元素及び臭素酸イオン, 塩素酸イオン などの陰イオンの共存による比較的大きな減感干渉が観察 された。また，七素，ビスマス，アンチモン及びセレンと
同様に，水素化物生成する元素である鉛，スズ，テルル （セレンに対しては干渉しない）についても減感干渉が観 察された．更にゲルマニウム，インジウム及びチタンの共 存による減感干渉がセレン測定の場合にだけに観察され た。

\section{$3 \cdot 5$ 鉄鋼分析への応用}

鉄鋼中の微量ヒ素, ビスマス，アンチモン及びセレンを 定量する場合には，先に Table 4 に示したように，主成分 である鉄による干渉を考慮しなければならない. 水素化物 生成反応の溶液中で鉄 (II) はヒ素, ビスマス，アンチモ ン及びセレンの測定には全く干渉を示さなかったが，鉄 （III）は 4 元素の定量に負の干渉を示す（Table 4 参照). 鉄鋼を王水で溶解した溶液中では鉄はすべて 3 価状態で あると考えられるので，水素化物生成反応の直前に鉄(III) を鉄 (II) に還元することを検討した。この鉄の還元剤と して, チ才尿素 ${ }^{10226) 28}$ と L-アスコルビン酸1127/28)を用いて その最適濃度を検討した。その結果，L-アスコルビン酸を 試料溶液に加えて測定したとき，セレンの発光強度が減少 することを確認した。これは L-アスコルビン酸によってセ レンが 0 価に還元されたことによるものと考えられる. ここで，オンライン（Fig. 1のb）で還元剤を添加し，3 価の鉄だけを還元することを試みた。素，ビスマス，ア ンチモン及びセレンのみの発光強度を 100 として, 鉄(III) 


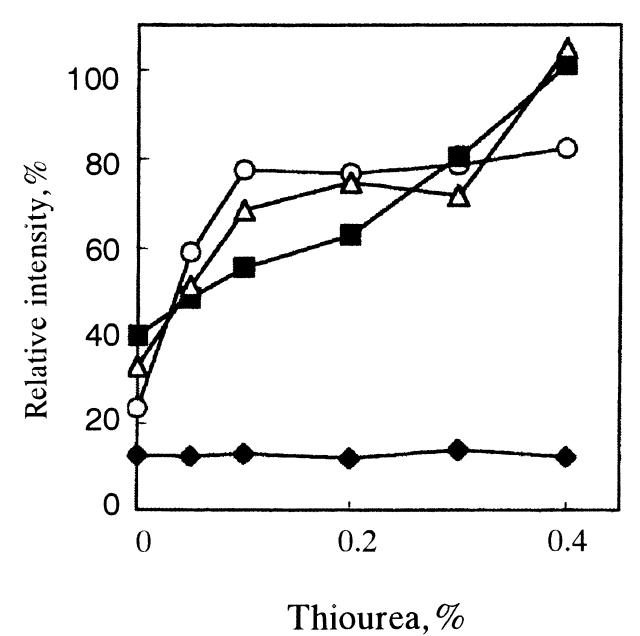

Fig. 4 Effect of thiourea concentration on emission intensity of $\mathrm{As}(\bigcirc)$, $\mathrm{Bi}(\square)$, $\mathrm{Sb}(\triangle)$ and $\mathrm{Se}(\diamond)$ in the presence of $5000 \mu \mathrm{g} \mathrm{Fe}(\mathrm{III}) / \mathrm{ml}$

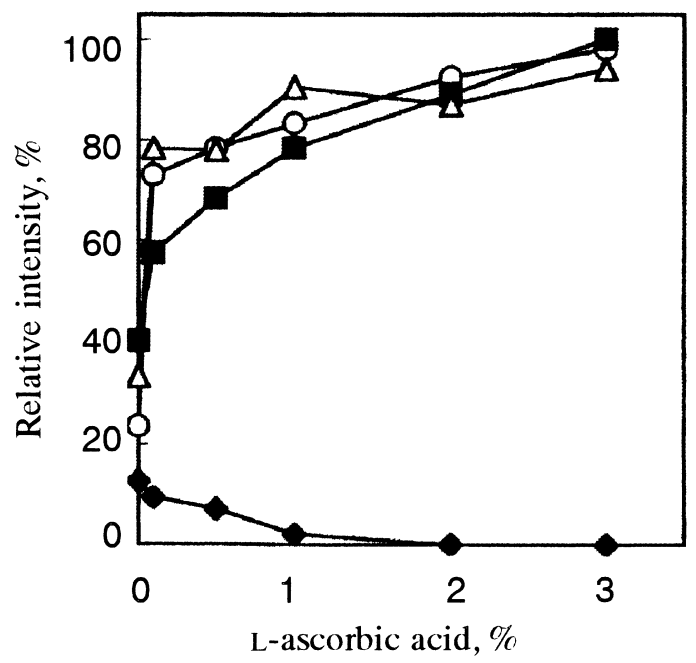

Fig. 5 Effect of L-ascorbic acid concentration on emission intensity of As $(\bigcirc), \operatorname{Bi}(\square), \operatorname{Sb}(\triangle)$ and $\mathrm{Se}(\boldsymbol{)})$ in the presence of $5000 \mu \mathrm{g} \mathrm{Fe}(\mathrm{III}) / \mathrm{ml}$
が $5000 \mu \mathrm{g} / \mathrm{ml}$ 含むヒ素，ビスマス，アンチモン及びセレ ンの混合溶液にチオ尿素と L-アスコルビン酸の濃度をそれ ぞれ $0.05 \sim 0.4 \%$ と $0.1 \sim 3 \%$ の濃度範囲で変化させて加 えた。そのときのヒ素, ビスマス, アンチモン及びセレン の発光強度を測定し，その相対值を Fig. 4 及び 5 に示す. チオ尿素を用いたとき，その濃度を $0.4 \%$ に調整すること により，アンチモンとビスマスはほぼ100\%，ヒ素は約 $80 \%$ まで発光強度が回復した。しかし，チ才尿素濃度を 大きくしても，七レンの発光強度に変化はなかった。ま た，L-アスコルビン酸を用いたとき，その濃度が $3 \%$ 以上 で, ヒ素, ビスマス及びアンチモンの発光強度もほぼ $100 \%$ 回復したが, セレンの発光強度は得られなくなった. これらの結果より, チオ尿素と L-アスコルビン酸を用いて, 4 元素すべての発光強度を回復させることができなかった ので，実際の鉄鋼分析では標準添加法を用いた。試料溶液 の調製操作は，2.3に示したとおりである。なお，この一 連の操作中に試料の溶解に用いた硝酸が共存しているの で，その影響が心配されたが，試料溶液中でのヒ素，ビス マス，アンチモン及びセレンの添加・回収試験を行い，ほ ほ 100\%の回収を得ることができた．本法を用いて分析 した定量結果を Table 5 に示す。その結果，NIST 361 の ビスマスは測定できなかったが, その他の分析值は保証值 とほぼ一致した。また，鉄の干渉抑制剤としてのチオ尿素 をオンラインで導入した場合では，チ才尿素を導入しない 場合と比較して精度が少しわるくなったが，どちらの方法 で測定しても得られた分析值は保証值とほぼ一致した。ま た，鉄鋼分析において，干渉を示す主成分の鉄等を抽出・ 除去しないで，水素化物生成-ICP-AES/MS 法を適用し， 多元素同時測定した報告 ${ }^{29)}{ }^{30)}$ は比較的少ないため，本法は 迅速な測定法として有用である。

\section{4 結 言}

試料溶液の導入に水素化物生成法を用いたヒ素, ビスマ ス，アンチモン及びセレンの同時定量に関する高出力 $\mathrm{N}_{2-}$ MIP-AES の基礎的な検討を行った結果, 溶液噴霧法と比 較して大幅な感度の向上が観察された。また，本法を鉄鋼

Table 5 Simultaneous determination of arsenic, bismuth, antimony and selenium in steels by high power N2-MIP-AES with hydride generation

\begin{tabular}{|c|c|c|c|c|c|c|c|c|}
\hline \multirow{2}{*}{ Sample } & \multicolumn{4}{|c|}{ Certified value $/ \mu \mathrm{g} \mathrm{g}^{-1}$} & \multicolumn{4}{|c|}{ Present work $/ \mu \mathrm{g} \mathrm{g}^{-1 \mathrm{a})}$} \\
\hline & Arsenic & Bismuth & Antimony & Selenium & Arsenic & Bismuth & Antimony & Selenium \\
\hline NIST 361 & 170 & $(40)^{c)}$ & 42 & 40 & $\begin{array}{c}179 \pm 8 \\
\left.(179 \pm 13)^{d}\right)\end{array}$ & $\begin{array}{l}\text { N.D. } \\
\text { N.D. }\end{array}$ & $\begin{array}{c}39 \pm 6 \\
(42 \pm 3)\end{array}$ & $\begin{array}{c}37 \pm 5 \\
(34 \pm 4)\end{array}$ \\
\hline NIST 363 & 100 & $(80)$ & 20 & 16 & $\begin{array}{c}94 \pm 2 \\
(89 \pm 9)\end{array}$ & $\begin{array}{c}73 \pm 8 \\
(73 \pm 9)\end{array}$ & $\begin{array}{c}19 \pm 1 \\
(19 \pm 9)\end{array}$ & $\begin{array}{c}19 \pm 3 \\
(16 \pm 8)\end{array}$ \\
\hline
\end{tabular}

a) The mean \pm standard deviation, based on 5 replicate determinations; b) Not determinable.; c) Referrence value.; d) Obtained by using thiourea as a releasing reagent 
中のヒ素，ビスマス，アンチモン及びセレンの同時定量に 適用した結果, 鉄鋼標準試料中に含まれるヒ素, ビスマス, アンチモン及びセレンの同時定量值は, それぞれの標準值 とよく一致する分析值が得られ，本法の有用性を実証する ことができた。なお， $3 \cdot 2$ に示したように，検出限界值が 各元素の単元素定量の場合と比べて高くなり, 感度が低下 したが，本法は迅速測定として十分に有効である.

最後に, 本研究は日本学術振興会科学研究費補助金基盤研究 C （No.13650872）及び日本鉄鋼協会の「スクラップ利用拡大に伴う 鋼中の微量不純物分析法の開発」研究会によるものであり, ここ に記して謝意を表明する。

$\left(\begin{array}{l}2002 \text { 年 } 9 \text { 月, 日本分析化学会 } \\ \text { 第 } 51 \text { 年会において一部発表 }\end{array}\right)$

\section{文献}

1) Y. Okamoto: Anal. Sci., 7, 283 (1991).

2) Y. Okamoto: J. Anal. At. Spectrom., 9, 745 (1994).

3) M. Ohata, N. Furuta: J. Anal. At. Spectrom., 12, 341 (1997).

4) K. Ogura, H. Yamada, Y. Sato, Y. Okamoto: Appl. Spectrosc., 51, 1496 (1997).

5) K. Oishi, T. Okumoto, T. Iino, M. Koga, T. Shirasaki, N. Furuta: Spectrochim. Acta, 49B, 901 (1994).

6) M. Ohata, N. Furuta: J. Anal. At. Spectrom., 13, 447 (1998).

7) E. Bulska, P. Tschöpel: Anal. Chim. Acta, 271, 171 (1993).

8) M. Ohata, H. Ota, M. Fushimi, N. Furuta: Spectrochim. Acta, 55B, 1551 (2000).

9) Z. Zhang, K. Wagatsuma: Spectrochim. Acta, 57B, 1247 (2002).

10) T. Nakahara, Y. Li : J. Anal. At. Spectrom., 13, 401 (1998)

11) 中原武利, 李 一木, 竹内啓貴, 二村 実: 鉄と
鋼, 85, 97 (1999).

12) 松本明弘，大枝淳能，中原武利：鉄と鋼, 87, 449 (2001).

13) A. Matsumoto, A. Oheda, T. Nakahara: Anal. Sci., 17 (Supplement), i963 (2001).

14) 松本明弘, 竹内啓貴, 中原武利: 鉄と鋼, 88, 270 (2002).

15) 松本明弘, 大枝淳能, 中原武利：鉄と鋼, 89, 587 (2003).

16) P. Fodor, R. M. Barnes: Spectrochim. Acta, 38B, 229 (1983).

17) T. Nakahara: Prog. Anal. At. Spectrosc., 6, 163 (1983).

18) T. Nakahara: "Sample Introduction in Atomic Spectrometry”, Edited by J. Sneddon, p. 255 (1990), (Elsevier, Amsterdam).

19) T. Nakahara: Spectrochim. Acta Rev., 14, 95 (1991).

20) T. Nakahara: "Advances in Atomic Spectroscopy", Vol. 2, Edited by J. Sneddon, p. 139 (1995), (JAI Press, Greenwich, Connecticut)

21) J. Dedina, D. L. Tsalev: "Hydride Generation Atomic Absorption Spectrometry”, p. 19 (1995), (John Wiley, Chichester)

22) J. Murphy, G. Schlemmer, I. L. Shuttler, P. Jones, S. J. Hill: J. Anal. At. Spectrom., 14, 1593 (1999).

23) T. Nakahara: Anal. Chim. Acta, 131, 73 (1981).

24) R. K. Anderson, M. Thompson, E. Culbard: Analyst, 111, 1143 (1986).

25) O. Muñoz, D. Véles, M. L. Cervera, R. Montoro: J. Anal. At. Spectrom., 14, 1607 (1999).

26) H. Uggerud, W. Lund: J. Anal. At. Spectrom., 10, 405 (1995).

27) T. Ashino, K. Takada, K. Hirokawa: Anal. Chim. Acta, 297, 443 (1994).

28) P.-k. Hon, O.-w. Lau, S.-k. Tsui : J. Anal. At. Spectrom., 1, 125 (1986).

29) 今北 毅，乾 道春，浜田啓志，谷口政行，中原 武利：鉄と鋼, 85, 724 (1999).

30) S. Chanvaivit, I. Brindle: J. Anal. At. Spectrom., 15, 1015 (2000).

\section{要旨}

新しい夕イプの高出力（1 kW） 窒素マイクロ波誘導プラズマ（MIP） を励起源に用いて，通常の試料導 入の方法である溶液噴霧法と水素化物生成法を適用して，ヒ素，ビスマス，アンチモン及びセレンの発光分 光分析の比較を行った。 ヒ素，ビスマス，アンチモン及びセレンの発光強度に影響を及ぼす種々の測定パラ メーターについて最適化を行い，その最適条件下で得られた検出限界 $(3 \sigma)$ は，水素化物生成法の場合， ヒ素，ビスマス，アンチモン及びセレンでそれぞれ 7.80，131，14.50 及び $28.99 \mathrm{ng} / \mathrm{ml}$ であった。更に， 本法を鉄鋼中のヒ素，ビスマス，アンチモン及びセレンの同時定量に適用した。試料溶液を $5 \mathrm{M}$ の塩酸溶 液中で 20 分間, $80^{\circ} \mathrm{C}$ で加温し，50\% のヨウ化カリウムをオンラインで添加してヒ素，アンチモン及びセ レンを予備還元し，標準添加法を用いた。その結果，鉄鋼標準試料中に含まれるヒ素，ビスマス，アンチモ ン及びセレンの同時定量值は，それぞれの標準值とよく一致する分析值が得られ，本法の有用性を実証する ことができた。 